\title{
Kinetics of blood neutrophil and lymphocyte count in critically ill neutropenic patients with hematological malignancies
}

\author{
Andry Van de Louw* (iD
}

In critically ill patients with hematological malignancies (HM), neutropenia and lymphopenia often coexist, whether related to HM or critical illness immunoparalysis [1]. Both cytopenias expose patients to increased risk of infection and possibly mortality $[1,2]$. However, little is known about the kinetics of neutrophil and lymphocyte count in neutropenic patients, which might affect the risk of serious infections in this vulnerable population.

We aimed to describe the course of blood neutrophil and lymphocyte count over time in adult patients with $\mathrm{HM}$ admitted to the ICU with severe neutropenia (neutrophil count $\leq 0.5 \times 10^{9} / \mathrm{L}$ within $24 \mathrm{~h}$ of ICU admission) between 2008 and 2018 .

All neutrophil and lymphocyte counts during hospital admission were collected along with demographics, underlying HM, main laboratory values on ICU admission, vital organ support in ICU and hospital mortality.

We included 210 patients (59\% males, median age 61 [IQR 47-67] years), mostly with acute leukemias (66\%) and lymphomas (22\%) (Table 1). Vasopressors, invasive mechanical ventilation and renal replacement therapy were required in $44 \%, 42 \%$ and $8 \%$ of patients, respectively. Hospital mortality was $40 \%$.

Figure 1a displays the course of blood neutrophil and lymphocyte counts over time: The mean neutrophil count sharply decreased to reach its nadir (mean \pm SEM $\left.0.19 \pm 0.17 \times 10^{9} / \mathrm{L}\right)$ on ICU admission with subsequent re-increase. The duration of severe neutropenia

*Correspondence: avandelouw@pennstatehealth.psu.edu Division of Pulmonary and Critical Care Medicine, Penn State Health Milton S Hershey Medical Center, 500 University Dr, Hershey, PA, USA was 6 (3-12) days for survivors. By contrast, the lymphocyte count followed a flat curve with mean values consistently $\leq 0.5 \times 10^{9} / \mathrm{L}$ throughout admission. The mean \pm SEM lymphocyte count on ICU admission was $0.35 \pm 0.02 \times 10^{9} / \mathrm{L}$. Severe lymphopenia $\left(\leq 0.5 \times 10^{9} / \mathrm{L}\right)$ was present on ICU admission in 137 patients, and its duration was 10 (4-17) days for survivors. Severe lymphopenia persisted for more than 3 and 7 days in 157 (75\%) and $109(52 \%)$ patients, respectively.

The slope of neutrophil count decline and recovery was sharper in survivors than in non-survivors (Fig. 1b), whereas no discernable difference was observed for lymphocyte count (Fig. 1c). In survivors, neutrophil count was significantly higher between day 2 and day 5 , whereas no difference with non-survivors was observed at any time for lymphocyte count.

The lymphopenia in our patients was more severe than in general ICU populations, where lymphocyte counts of $0.5-1 \times 10^{9} / \mathrm{L}$ were reported $[3,4]$. Whether this is related to $\mathrm{HM}$ and chemotherapy or reflects a more pronounced critical illness immunoparalysis remains unclear. In a similar analysis in 407 ICU patients with HM but without neutropenia, we observed a similar flat curve for the lymphocyte count throughout admission but at a level close to $0.8 \times 10^{9} / \mathrm{L}$ (not shown), similar to reports in unselected ICU patients $[3,4]$. Second, while lymphopenia has been well documented in critically ill patients $[3,4]$, most studies focused on ICU admission values with little information on kinetics. Lymphopenia in our population was very prolonged. We did not observe a difference in absolute values or kinetics between survivors and non-survivors, but studies are warranted to ascertain original author(s) and the source, provide a link to the Creative Commons licence, and indicate if changes were made. The images or other third party material in this article are included in the article's Creative Commons licence, unless indicated otherwise in a credit line to the material. If material is not included in the article's Creative Commons licence and your intended use is not permitted by statutory regulation or exceeds the permitted use, you will need to obtain permission directly from the copyright holder. To view a copy of this licence, visit http://creativecommons.org/licenses/by/4.0/. The Creative Commons Public Domain Dedication waiver (http://creativeco mmons.org/publicdomain/zero/1.0/) applies to the data made available in this article, unless otherwise stated in a credit line to the data. 


\section{A Cell count $\left(\times 10^{9} / \mathrm{L}\right)$}

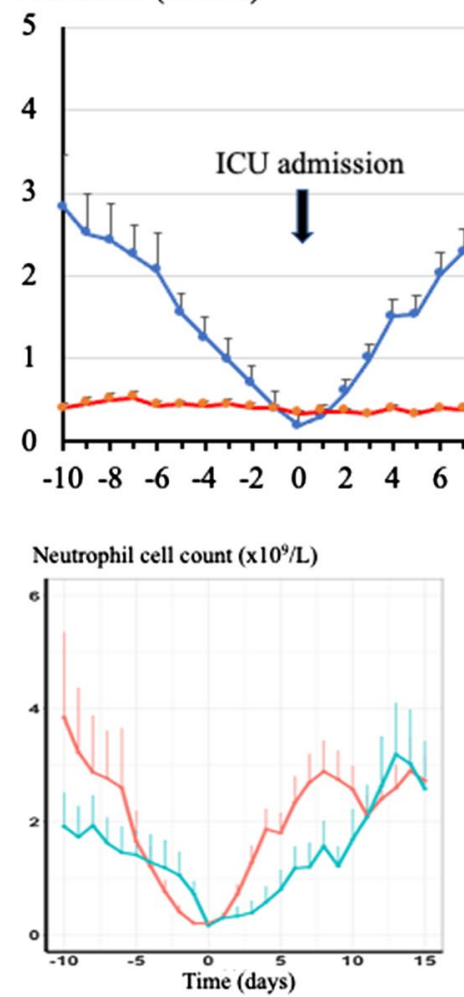

Fig. 1 Kinetics of blood neutrophil and lymphocyte counts in 210 critically ill neutropenic patients. a Mean + SEM of blood neutrophil (blue) and lymphocyte (red) counts over time, from 10 days prior to ICU admission to 30 days after ICU admission. ICU admission is at day 0 . b Mean + SEM of blood neutrophil count over time, from 10 days prior to ICU admission to 15 days after ICU admission, for survivors (red) and non-survivors (blue). ICU admission is at day 0. c Mean + SEM of blood lymphocyte count over time, from 10 days prior to ICU admission to 15 days after ICU admission, for survivors (red) and non-survivors (blue). ICU admission is at day 0

the effect of lymphopenia in this specific population. Finally, the median neutropenia duration was 6 days in our patients with a faster recovery in survivors. Another study reported a similar duration of neutropenia and lower mortality in patients who experienced neutropenia recovery in the ICU [5].

Several important points were not addressed in this study and are avenues for future research: (1) the association between lymphocyte kinetics and infections, (2) the qualitative aspect of neutrophil and lymphocyte function, which may remain altered beyond count recovery [6], and (3) the effect of hematopoietic growth factor administration in this setting.

In summary, critically ill neutropenic patients experience severe and prolonged lymphopenia. Our data suggest that survival might be associated with faster neutropenia recovery. 
Table 1 Patients' main characteristics

\begin{tabular}{|c|c|}
\hline & Patients $(n=210)$ \\
\hline Male gender, $n(\%)$ & $124(59 \%)$ \\
\hline Age (years) & $61(47-67)$ \\
\hline \multicolumn{2}{|l|}{ Hematological malignancy, $n$ (\%) } \\
\hline Acute leukemia & 139 (66\%) \\
\hline Non-Hodgkin lymphoma & $41(20 \%)$ \\
\hline Hodgkin lymphoma & $5(2 \%)$ \\
\hline Multiple myeloma & $14(7 \%)$ \\
\hline Other & $11(5 \%)$ \\
\hline \multicolumn{2}{|l|}{ Laboratory on ICU admission } \\
\hline Neutrophil count, $\times 10^{9} / \mathrm{L}$ & $0.06(0.02-0.28)$ \\
\hline Lymphocyte count, $\times 10^{9} / \mathrm{L}$ & $0.14(0.04-0.42)$ \\
\hline White blood cell count, $\times 10^{9} / \mathrm{L}$ & $0.34(0.07-1.16)$ \\
\hline Platelet count, $\times 10^{9} / \mathrm{L}$ & $24(13-43)$ \\
\hline Hemoglobin, g/dL & $7.9(7.1-8.8)$ \\
\hline Creatinine, mg/dL & $1.13(0.75-1.61)$ \\
\hline $\mathrm{HCO}_{3}{ }^{-}, \mathrm{mmol} / \mathrm{L}$ & $22(19-26)$ \\
\hline Lactate, $\mathrm{mmol} / \mathrm{L}(n=117)$ & $1.8(1.2-3.4)$ \\
\hline \multicolumn{2}{|l|}{ Vital organ support in the ICU } \\
\hline Vasopressors, n (\%) & $92(44 \%)$ \\
\hline Mechanical ventilation, $n(\%)$ & $88(42 \%)$ \\
\hline Renal replacement therapy, $n(\%)$ & $17(8 \%)$ \\
\hline Hospital mortality, n (\%) & $83(40 \%)$ \\
\hline
\end{tabular}

Results are presented as median (interquartile range) and number (percentage) for continuous and categorical variables, respectively

\section{Abbreviations}

HM: Hematological malignancies; ICU: Intensive care unit; SEM: Standard error of the mean.

\section{Acknowledgements}

Not applicable.

\section{Author's contributions}

AV designed the study, collected and analyzed the data and wrote the manuscript. The author read and approved the final manuscript.

\section{Availability of data and materials}

All data generated or analyzed during this study are included in this published article.

\section{Declarations}

\section{Ethics approval and consent to participate}

This study was approved by the Penn State Health Institutional Review Board (Number 10872), and informed consent was waived due to its retrospective design.

\section{Consent for publication}

Not applicable.

\section{Competing interests}

The author declares that he has no competing interests.

Received: 18 July 2021 Accepted: 19 August 2021

Published online: 30 August 2021

\section{References}

1. Carcillo JA, editor. Critical illness stress-induced immune suppression. Berlin: Springer; 2007.

2. Georges Q, Azoulay E, Mokart D, Soares M, Jeon K, Oeyen S, et al. Influence of neutropenia on mortality of critically ill cancer patients: results of a meta-analysis on individual data. Crit Care. 2018;22(1):326.

3. Hohlstein P, Gussen H, Bartneck M, Warzecha KT, Roderburg C, Buendgens $L$, et al. Prognostic relevance of altered lymphocyte subpopulations in critical illness and sepsis. J Clin Med. 2019;8(3):353.

4. Shankar-Hari M, Fear D, Lavender P, Mare T, Beale R, Swanson C, et al. Activation-associated accelerated apoptosis of memory B cells in critically III patients with sepsis. Crit Care Med. 2017;45(5):875-82.

5. Darmon M, Azoulay E, Alberti C, Fieux F, Moreau D, Le Gall JR, et al. Impact of neutropenia duration on short-term mortality in neutropenic critically ill cancer patients. Intensive Care Med. 2002;28(12):1775-80.

6. Ramaprasad C, Pouch S, Pitrak DL. Neutrophil function after bone marrow and hematopoietic stem cell transplant. Leuk Lymphoma. 2010;51(5):756-67.

\section{Publisher's Note}

Springer Nature remains neutral with regard to jurisdictional claims in published maps and institutional affiliations.

\section{Funding}

None.

Ready to submit your research? Choose BMC and benefit from:

- fast, convenient online submission

- thorough peer review by experienced researchers in your field

- rapid publication on acceptance

- support for research data, including large and complex data types

- gold Open Access which fosters wider collaboration and increased citations

- maximum visibility for your research: over 100M website views per year

At BMC, research is always in progress.

Learn more biomedcentral.com/submissions 